IdeAs

Idées d'Amériques

$7 \mid 2016$

Cinéma et histoire dans les Amériques

\title{
The poetics of Los Angeles: Discussing the hyperreal capital of the world with Wanda Coleman
}

Poétiques de Los Angeles: À propos de la capitale mondiale de l'hyperréel, une discussion avec Wanda Coleman

Poéticas de Los Ángeles: una discusión sobre la capital mundial del

hiperrealismo con Wanda Coleman

\section{Charles Joseph}

\section{OpenEdition}

Journals

Electronic version

URL: https://journals.openedition.org/ideas/1422

DOI: $10.4000 /$ ideas. 1422

ISSN: 1950-5701

\section{Publisher}

Institut des Amériques

Electronic reference

Charles Joseph, "The poetics of Los Angeles: Discussing the hyperreal capital of the world with Wanda Coleman ", IdeAs [Online], 7 | 2016, Online since 29 June 2016, connection on 18 October 2022. URL: http://journals.openedition.org/ideas/1422 ; DOI: https://doi.org/10.4000/ideas.1422

This text was automatically generated on 18 October 2022 .

\section{c)}

Creative Commons - Attribution-NonCommercial-NoDerivatives 4.0 International - CC BY-NC-ND 4.0 https://creativecommons.org/licenses/by-nc-nd/4.0/ 


\title{
The poetics of Los Angeles: Discussing the hyperreal capital of the world with Wanda Coleman
}

\author{
Poétiques de Los Angeles : À propos de la capitale mondiale de l'hyperréel, une \\ discussion avec Wanda Coleman \\ Poéticas de Los Ángeles: una discusión sobre la capital mundial del \\ hiperrealismo con Wanda Coleman
}

Charles Joseph

Born in 1946 in Los Angeles, Wanda Coleman (née Evans) grew up in Watts when it was still a WASP suburb. She witnessed the 'white flight' which turned the neighborhood into what many would start to call a ghetto, and experienced the increasing oppressiveness of an urban-led segregation that would affect each area of her life. She lived the Watts rebellion from the inside and witnessed the 1992 riots from further away, but those events crystallized notions of illusion, history and narratives upon which most of her work has been grounded. Sometimes known as the "L.A. Blueswoman" or the "unofficial poet laureate of Los Angeles," Wanda Coleman was a poet whose many voices uttered uncompromising truths in order to serve her one ultimate goal: rehumanize the dehumanized. She thus produced a work made of ten books of poetry, two short story collections, two books of essays, one novel, three records and countless articles through which she mapped the Angeleno society as she lived it, writing it vividly through voiced experiences, invoking thus literary images to battle the superimposed built imagery created by the city's dream factory.

As I started to work on my PhD dissertation entitled "Being and Writing (from) Los Angeles: Wanda Coleman," I was able to come into contact with Coleman herself via email through her publisher. We corresponded quite often over five years and she always made herself available to answer my many interrogations, enquiries 
and requests. Thanks to an AFEA research grant, I was able to work in Los Angeles for over a month in 2011 and met Wanda Coleman for the first time then. The following interview was conducted at the Sheraton Suite Hotel of San Diego on Saturday October 8th, 2011, the first time that we met in person. Wanda Coleman was invited to the San Diego book fair and agreed to spend some time and talk with me before and after her reading. In this exchange, Coleman leads us through her poetics and how her journey and struggle in Los Angeles has shaped her motivations and her authorship. Wanda Coleman passed away in Los Angeles in November 2013.

CHARLES JOSEPH: Let's maybe start with a broader enquiry regarding the literary landscape in which you evolve and which you built around you. There are numerous references within your work of other authors and poets but I think there are a lot more that do not appear in the pages of your books, could you expand a little more on them?

Wanda Coleman: I tend to be rather conservative when it comes to people. I am basically an introvert. (I call myself a "functional extrovert" to account for my public performance aspect.) It takes a long time for me to make friends. But once I do, I stay a friend for a very long time. My closest friends who are also poets are Stephen Kessler, a prize-winning translator in Spanish, who now lives in Santa Cruz, California and is a long-time resident of the region. Originally from L.A., he and his new wife Daniela (a poet and translator in French and Rumanian) are personal friends and know a good deal about my private trials through phone calls and letters. I have given Stephen written permission to some day publish our correspondence. I believe I owe him that. He has been an extremely good friend to me, even when we disagree. We have known one another since 1979.

My dearest friend of forty years is nearing her $80^{\text {th }}$ birthday. Her name is Sylvia Rosen and was the former director of the Valley Contemporary Poets reading series with poet Nan Hunt. We met in Diane Wakowski's Cal Tech poetry workshop circa 1971. She later studied privately with Clayton Eshleman, after I studied with Clayton in his Writing workshop in the Reseda-Sherman Oaks area, circa 1973. Another friend who was almost a lover, was poet F.A. Nettelbeck. He was very close to Stephen. He died in January of this year.

My other poet friends/mentors are deceased: John Thomas and his wife Philomene Long-Thomas. He was a mentor and introduced me to the works of Pound, Elliot and Bukowski (one of his buddies). She became my friend at the end of her life. My friend-in-poetry, e.e. miller is one of the literary marchers of Washington D.C., a professor at Bennington and Howard University but our correspondence appears in The Riot Inside Me so you might already know about him. Allen Ginsberg liked my work and invited me to Naropa, and to read with him in Oakland. He included me in two of his last anthologies, one published in France, by the way.

cJ: What about the Los Angeles-based literary scene...? It suffered rather significantly from the city's entertainment-industry that hid the vibrant literary culture growing underneath. The Beyond Baroque became a rallying place for many authors of the city, was it for you as well?

WC: You're absolutely right and yes it was. There are a number of poets who have been friends, enemies and surrogate classmates as I like to call them. Since I have unfortunately never been able to complete my formal education, I like to refer 
to those poets who gravitated to the Beyond Baroque Literary Center in Venice Beach as classmates-people who I liked or disliked in varying degrees and who moved in and out of my literary life as I lived the city: Paul Brooks, Jack Grapes, Laurel Ann Bogen, Bill Mohr, Harry Northop, Holly Prado, Eloise Klein Healy, Kate Braverman, Dennis Cooper, Jim Krusoe, Bob Flanagan, Rod Bradley (also a fine photographer), Manazar Gamboa, Robert "Greenie" Greenfield, LeLand Hickman-all "classmates." There were two younger poets who used to hang out at Beyond Baroque on workshop nights and sometimes I would talk to them when no one else would. They became a rock group, "X"-Exene Cervenka and John Doe. I think of them as distant acquaintances, people I read and performed with in the 80s (Twin Sisters) along with Henry Rollins (Black Flag).

There are a couple of poets who comprised "the Long Beach" faction, and gravitated around Elliot Fried and Gerald Locklin. They are Charles Harper Webb and Ron Koertge. When poet David St. John came to town, and settled in L.A., we eventually crossed paths and like one another at a busy distance. Some of the younger generation: actor, S.A. Griffin; rock star Beck, actress Amber Tamblyn.

Among my general L.A. poetry community "classmates": I count Luis Rodriguez, Michael C. Ford (one of the first persons to publish me), David Trinidad (now living in Chicago), Lewis McAdams (L.A. River activist), Doug Messerli, Israel Helpern and his ex-wife Liza Jane Braude, and Pamala "LaLoca" Karol. A generation before us, John "Bill" Harris originally published BACHY, considered by many to be L.A.'s first serious poetry magazine; he is a senior member of that class and one of the founders of the Beyond Baroque Wednesday night workshop.

Comedienne Suzanne Lummis (granddaughter of Charles Fletcher Lummis, first City Editor of the Los Angeles Times and one of the founding fathers of L.A.) showed up on the scene in the late 70s, and is a friend-in-poetry for me and my husband Austin Strauss. Linda Albertano, who toured with Alice Cooper back in the day, is another friend-in-poetry. I love performing with her; although, it's rare-the last time we were on stage together was for Allen Ginsberg's 1997 memorial at the V.A. Hospital in west L.A.

As for Black poets, there weren't many. L.A. is very hard on the African-American spirit, and toward the end of the 20th Century, the men tended to leave the city as soon as possible, unable to tolerate "the heat"-the constant harassment by the LAPD. And the male poets weren't readily embraced in at Beyond Baroquedepending on who the director was at any given point. A new generation of Black poets have sprung up, but they are much my junior and are so many I can't possibly know them all. The Black poets and men of color I was acquainted with were people I met and/or hung out with prior to 1975: Kamau Daaood, Eric Priestly, Quincy Troupe (now lives in New York, and who invited me there for a publication part of Renaissance Noire, the magazine he edits. When he left California behind a scandal, I took his heat-most Whites in the literary circles assuming we were close buddies), Odie Hawkins (, mainly a novelist, martial arts specialist, and still a friend-seen rarely), The Watts Prophets-who did the first-ever rap record titled Rap.

There are several older Black women, who are younger than me, who are known as poets: Merilene Murphy, Hazel Clayton Harrison, Lynn Thompson and Pamela Ward. Michelle T. Clinton (Black Angeles, High Blood Pressure) came to town in the 80s, 
only to suffer an "identity crisis", have a nervous breakdown and disappear back to her home town of Berkeley. Harryette Mullen and I have jockeyed around on the same stomping ground since the 70s. Our encounters are rare but we are acquainted across the distance. I was on a panel she moderated at the New School in San Francisco, for a literary conference at which I presented my paper "On Theoloniousism," in which I put forth my writing theory of "the jazz principle."

Among the new Black Male Talent: Michael Datcher, Anthony Lee, and Douglas Kearney. While on my last trip to New York, I got to holler at poet-performer Jayne Cortez, who looked as beautiful as ever! She knew/dated my first husband, Jerry Coleman, and we double-dated with her and Horace Tapscott back in the day, before she married Ornette Coleman.

Other Black poets I have interacted with include Willie Sims, Arthur Pfister, Keith Antar Mason (originally from St. Louis, now goes by the name "Raven"), K. Curtis Lyle, Paul Beatty (now in NYC), playwright Lynn Manning (who is blind, and who I gave private lessons to for a brief spell in the late 80s), Emory Evans (from Studio Watts in the 60s) and Kalamu ya Salaam (from New Orleans) - Doris Davenport and Ruth Forman (appeared on the Poetry Connexion).

Old poetry friends and associates cross the racial boundaries: Chungmi Kim (Korean), Reuben Martinez, Sesshu Foster, Dan Kwong, Russell Leong, Jimmy Baca. You may see my work in the publications or anthologies they have edited in the past. Chungmi lives in the D.C. area, now but when she comes to this coast we try to get together. Sesshu is also a translator and well-acquainted with Stephen Kessler who introduced me to his work. Dan Kwong followed my performance energy and is associated with the Highways Performance space. A new friend-in-poetry is Truong Tran (see our correspondence in Letters to Poets, Firestone \& Lomax, Editors).

As I have traveled, I have made poet-friends, people I like if maintaining the relationship is almost impossible: performance marcher and Nuyorican Café/Bowery Poetry Club founder Bob Holman, poet Karl Gartung and his wife Anne Kingsbury in Milwaukee at Woodland Pattern, Ammiel Acalay at CUNY, Afaa Michael Weaver, Ralph LaCharity, Jeffrey Renard Allen, Tara Betts, Rachel Levine (from Chicago, now in Berkeley, on the periphery of my private life, she and her husband John Holman), Barry Silesky in Chicago (Another Chicago Magazine). Activist-poet Bobbi Sykes in Sydney, Australia. So I guess I've been terribly social for an introverted poet...

cJ: I guess you also came into contact with a tremendous amount of other poets while working at the KPFK radio station for "The Poetry Connexion" show?

WC: Indeed, for 14 years I co-hosted the Pacifica Radio interview program with my husband poet-painter Austin Strauss. We did over 400 shows and met as many poets and more during that time, between 1981 and 1996. (Between the two of us, we virtually know one or more persons in every English Department on every campus in the state of California.) Among those poets peripheral to my life were poet-artist Gordon Wagner (and wife Virgina), Robert "Bob" Peters, Terri Kennedy, Yvonne Dela Vega, Deena Metzger, Jesus Papoleto Melendez, Nicola Manning, Henry Morro, Martha Ronk, Peter Schneidre, Marilyn Chin, Jack Skelly, Max Benevidez, John/Jack Brander, Jim Cushing, Pete Fairchild, Joel Lipman (who featured Austin and I in a documentary TV show), Sharon Dubiago (a friend of Philomene Long's), Paul Hoover 
and his wife Maxine Chernoff, Mazizi Kunene, Lois Red Elk, Irish-American poet Tim Joyce, South African activist and poet Dennis Brutus, and Jack Micheline.

Other than Charles Bukowski and Carl Rakosi, some of my sibling writers at Black Sparrow Press also touched my life privately: Lucia Berlin, Michael Lally, Diane Wakoski (mentor), and Jenny Pommy Vega. I had a brief communication with Kenneth Fearing just before he died. I consider the work of Jack Spicer among my readerly influences.

Other friends-in-poetry include Paul Nelson (SPLAB) in Washington State, long time family friend Kika Warfield, Kush Cloudhouse in San Francisco, Murray Wolfe (and his wife Charlene, now in Iowa) who published my Dicksboro Hotel collection, Frances Dean Smith (deceased, part of the original Beyond Baroque organizers and Bukowski's ex-wife, mother of his only child Marina), Tim Congdon, Max Schwartz (now in Sacramento), Billy Jones and Penny Gasaway. Kate Gale and her husband Mark Cull of Red Hen Press have been friends-in-poetry and we are mutual supporters.

cJ: In Bathwater Wine you wrote your poem "The Sacred History of the Gone" after Henri Coulette, isn't he also one of your biggest influences given that he was the only formal teacher you had in you career?

WC: Absolutely yes. Henri Coulette whose poetry class I entered at Cal State L.A. in Fall 1964, is perhaps the most important influence of them all. I had to drop out, but managed to complete my studies and earn a " $\mathrm{C}$ ". He taught me the value of frank unbiased criticism, one thing that I try to perpetuate when I am now occasionally teaching. When I'm teaching, I've often encouraged students to be able to walk in someone else's shoes. If you're gonna be a good writer that's one quality to possess.

cJ: Empathy?

WC: Yes, you need that or to be somewhat of an empath anyway. D.H. Lawrence was one of the best to legitimately write in the voice of a woman, or to present female characters that, to me, seemed legitimate as women and worked as women. And there aren't too many... The opposite is even rarer. You know, it's become sort of a thing with comedians to cross gender and play at being a woman or at being feminine...or if they're straight being gay, I mean it's ironic because homosexuals have been acting since the job! And it's the same with African Americans. Having to present yourself as something other than what you are in order to work! So there's that acting within the acting, and sometimes that can be crippling to one's craft. I think that writing however, tends to give one an advantage as a writer if you can transcend your own circumstances...

cJ: And I guess facing the page, being on one's own may be easier to master one's mind, one's craft and one's projection rather than being part of a troop and being a comedian having so many influences coming from one's immediate surroundings. Being a writer, those influences are emanating from one's mind, from one's experience so I guess this is what you mean when you're talking about transcending oneself and one's circumstances?

WC: Yes, the circumstances are one thing but you sort of have to transcend the self. I enjoy when I'm teaching writing courses, challenging my students if they haven't done it already, to be in the skin of someone else, legitimately be in the skin, not just be "companattitude", or feedback or stereotypes about the other. 
cJ: Are you able to pinpoint those who are remaining on the surface? When you're asking them to write like that, do you find in their writings some archetypal identity construct that they use?

WC: Sometimes, especially if they've had strong emotional experiences. One young man, in one of the last courses I taught at CalArts, one young man's mother had just died, so he was in the process of grieving, and a lot of times anger accompanies death, the death of a loved one, because you're angry at the world, you're angry at them, you may be angry at God, you may be angry at a great number of reasons. This individual focused on his father, his anger was all on his father because his mother died of lung cancer and his father was a smoker. So his rage finally came out in something he brought to the session, and I thought that, you know, I'm not really into therapy, I don't feel that when I'm teaching I should act as a therapist, but I just addressed his situation with an anecdote about my father dying of lung cancer and he never smoked. So that at some point he was gonna have to reconsider this feeling about putting that blame on his father, and that at some point he's gonna have to walk into his father's shoes so to speak.

cJ: Your texts and poems, your work in general stands and speaks for itself so I won't necessarily ask too many things about specific pieces you wrote, what is more interesting is the overall articulation of the various formats you published over the years and the poetics motivating them, and how these poetics are linked with the city itself...

WC: Ooh... untranslatable right?!

cJ: In various interviews you gave a motto, or more appropriately a leitmotiv, that your primary objective as a poet, as an author is to rehumanize the dehumanized. Why don't we start from there?

WC: I have never published the phrase "rehumanize the dehumanized" except in proposals for teaching courses at various universities, during academic lectures, and in various biographical notes-some online. I started using this phrase sometime in the early 1980s when I began teaching writing workshops. I needed a phrase that encapsulated a type of writing process I favored. I used it to describe what I was doing in poems like "Emmett Till", and specifically poems I wrote that filled in the cultural gaps in newspaper articles (like my take on Latasha Harlins and the riots following the beating of Rodney King by police officers) where the victims or perpetrators were Blacks (as in my poem "David Polion"). I made up the phrase, as far as I know, and thought I was being original. However, as I often say when I lecture, there is such a thing as "simultaneity of thought (La simultanéité de la pensée)." Likeminded individuals come up with the same idea or thought independent of one another in different parts of the world. This process, favored by intellectuals in academe-and once relatively easy to document-has become "confused" or "complicated" by the digital paradigm shift and the success of the internet where communication of ideas is instant and the idea of originality exploded. In this case I used this phrase before hundreds of Americans for over a generation.

When working on IMAGOES, John Martin, my publisher at Black Sparrow Press, was amazed when he read several of the poems and commented: "Wanda, no one has ever said that before!," as if the notion of a young Black woman having a brain in her head, and saying something original, was completely foreign to him. In fact, I believe one of my ongoing problems, inherent in racism, is that people do not believe I am a thinker. They prefer to believe I intuit the poem or the story-or that someone else (like Austin) is really writing them, or helping me write them. Fortunately, I 
published a good deal of work before I met Austin in 1981 and had already established my local reputation as a poet and writer. It is highly probable that others began to use that phrase also and it began working its way into the American vocabulary. I have done this with other phrases, popularizing phrases I've heard in the ghetto for years, or coined on my own (for example: pimpmobile-a word I heard in the 70s, muthafatha or motherfather as one word which I made up, and my much-borrowed title "American Sonnet"-used by other poets without giving me credit).

I like to play on American adages or sayings. One of my favorites is a variation on "Wham, Bam, Thank you Ma'am" an old phrase that I believe originated in a bawdy couplet, author unknown. During the early 80s when feminism was raging, I had lots of fun when lecturing by changing it to "Wham, Bam, Thank you Sam." That phrase has worked its way into our slang vocabulary, and I've even had other women say it back to me-remarkably! Several observers of the literary scene have called me a catalyst and a barometer. I seem to have the gift of influencing those around me without necessarily being involved in the action myself, for example, my brief friendship with Charles Manson discussed in "Love-ins with Nietzsche" in The Riot Inside Me. I think I also have the gift of sensing shifts in the social dynamics of the body politic and emotional social currents.

cJ: Can you single out one period or one event that made you change your perspectives from self-preservation and a claim for respect towards the more global scale of rehumanization of L.A. territory? When did this shift, this change occur to you as a black woman and/or as a writer? Was it motherhood? 1992 South Central riots? Growing oppression by exponentially developing mass-media? All of the above, accumulating over one another?

WC: The shift started early with the televised exposes of Malcolm X. Knowing that such a man existed was like having spring water poured over my parched psyche. Racism as I encountered in the Unified Los Angeles School System had nearly murdered my spirit. This budding awareness was further encouraged during my first marriage which corresponded with the mid-to-end 1960s. My first husband Charlie Jerome (Jerry) Coleman gave me my first lessons on how the world really workedparticularly our American Government. He was very political and reintroduced me to my own people's history-knowing more about it than I had ever known or been exposed to, either at home or in school. My parents didn't know as much in quite the same way he did. We spent most of our days in L.A.'s political underground-from the NAACP Youth Council to the Black paramilitary, associating regularly with Betty Little, Malcolm's cousin and her husband Jamal Hakim. Jerry spent a brief spate with Ron Karenga as one of his "henchmen." It was quite a time. By the end of our marriage I had begun to outgrow Jerry, my knowledge outstripping his-which was a contributing factor to our break-up.

As a single Mom, I began to experience the hard realities of "dehumanization" as they became personal. As the years ensued and I chased my dreams in Hollywood as a scriptwriter, I began to understand that Hollywood censored my stories (and virtually any stories about the 1960-70s and political unrest-most of these stories (dramatic-only comedies were allowed), when told, done so with independent funding outside Hollywood; which is still true today.) Growing up in the southwest, I have always had an understanding of the importance of Image. But Hollywood put a spin on those lessons that I could not have anticipated. So you can nail my mounting awareness to the periods between 1964 and 1979-particularly February 1972 and 
August 1974 when I edited the first six issues of the Black men's magazine Players which featured black female nudes. By 1975 the shift was complete.

cJ: Racial matters also came into play as to how they biased your experience of the Angeleno American dream, didn't they? You mentioned earlier how long it has been for academics to be able to seriously study the dynamics of the African American community in Los Angeles outside the prism of the 1965 or 1992 riots?

WC : Indeed Charles... Here it is 2010, and I had to get this old to live this long to see a book on black Los Angeles ${ }^{1}$. And in talking about how black L.A. is the largest concentration of African Americans in the country outside of Cook County, Illinois, and I've had a very hard time communicating with my fellow African Americans in all the parts of the country and that's forced me to wonder, why is that? Someone said to me when I was travelling, "Oh I didn't know that there were any blacks in Los Angeles". Yeah! So I've had to fight through my relationship to the city, I've had to survive in it, and fight it, and to fight to survive in it, and then fight the city itself at the same time, in order to become.. well to Become, which has been extremely debilitating I don't think I've won the battle, I think I lost more!

cJ: Would you say that the battle was lost before it began?

WC: Well, yeah, certainly if you judge by the economy, but you could say that about the nation itself, that the war was over a long time ago. I think that's one of the reasons why voices like mine are so significant and have such a difficult time being heard. I received a letter from a friend talking about her discomfort with me and apologizing for it. It took her a number of years away from me, and it took her another interracial relationship for her to appreciate who I was. Even though I was living with her. At the time I was teaching down here (San Diego) and I was staying with her at her place, and it was very hard for her, we liked each other but it was very hard for us to connect, she's coming from a wealthy upbringing white upper class, and I'm, well, you know, at the exact opposite of that and L.A. kind of came between us in that way... The city or rather, this layer of Hollywood superimposed on it... You have this layer of illusion and people embracing the illusion layered on top of you. You have the usual things that may keep on in a subculture, first the skin color, you know, your slave origin, you have those problems, then you have gender, then you have the fact that I'm, you know a working class poor worker, and then there's this other thing about having to break through all of these layers, to use my intellect to get through all these layers. But the one that stuck the hardest was that of the city because I feel like it prevented me to connect properly with other African Americans... How do you get through this morass? And to explain that to someone who's from Harlem or D.C. or Chicago, or from other world centers, that can be a little bit difficult because most Americans define African Americans by certain criteria. People have certain expectations when they meet you, you're being judged by that, and the Los Angeles criteria on top of the rest was the one that ostracized me the most. It makes it extremely difficult, you're almost forced to find some way to break through all that glamour to be heard, like a boil. You have to somehow lance that right away and express the poison in order to have effective communication.

CJ: I won't give into the overall Maya Angelou controversy, much has been said on that if not everything. But what you're also referring to here makes me think of that article you first published in $\mathrm{KONCH}$ Magazine and later included in The Riot Inside Me entitled "Black on Black : Fear and Reviewing in Los Angeles." It concluded on the fact that you received much more attention about your review of Angelou's book rather than on your own poetry, and 
that this literary "black on black crime" revived an inherent fear rooted deep within the African American community, intellectual and otherwise, do you still believe that almost ten years after?

WC: Well, I don't know... Good question. The paradigm might seem like they've changed over the last few years but I believe that fear hasn't dissipated just because of Obama... Fear has governed the African American existence in this nation. Even today, when I encounter most African Americans, they are afraid. Underneath. They don't want to admit it, they don't wanna look at that or acknowledge it. But there is this fear that's there, and it comes larger, and comes out of the experience in the south, it comes out of slavery, this fear of separation, not only from our nation in which or where you're origins are and then Africa, but from your most intimates thoughts, from your parents, your sisters and brothers, all those things you identify with. But I was born and raised in the West. For some reason or other, for African Americans, the idea of coming west has become synonymous with a sort of emancipation, with the western territory as opening up, but I digress. My parents raised me totally without this fear. They too, believed that Los Angeles, West of West, was as opened up about race as they could find. They settled in the Watts neighborhood when they were the only African-American couple in a 4 block radius. They taught me, they constantly were reinforcing me, "I'm as good as anyone", they didn't tell me about racism. It told me about itself. It came along eventually, but the first five years of my life were fear-free. Until I entered the public school system, I thought of myself as this wonderful preacher, getting ready to explore the earth! And I didn't have any fear, I was utterly fearless. So when I encountered these people who were rooted in fear, that set us apart. I can recognize, I appreciate that fear, I understand it, but I don't share it.

cJ: Do you think that Education, as you mentioned the school system, has done its role in order to try and dissipate that fear? Or do you think it only kept it up by not addressing it more directly?

WC: I think the problem is to the extent that it is in the classroom or even in the overall school district organization or repartition. It's all part of say, an African American defense mechanism. They can close themselves off to the white world, that's a defense mechanism, you rejected me, I reject you. So you enter a home of an African American and you look on the bookshelf and you only see books by African Americans. You look into what they listen to and you only see African American artists. Only African American content, the art on the wall is by African Americans, or they put together, pastiche themselves, a lot of times it's not unusual to go in and the only whites you will see will be one of the Kennedys, or both of them, you know, Robert Kennedy and John Kennedy. So the images, the world that they create, reflects them because they can't truly open up to the outside world. If you turn on television, there's nothing on it that truly reflects the African American experience. Very little. And since Obama has been elected, my girlfriend and I we just roared, but I've never seen so many African Americans in front of the camera in my Life! But behind the cameras, there're still these huge disparities. So that's another lie for you. What you see on the screen, again that's going back to Hollywood, that's the illusion!

CJ: I'd like to continue on Hollywood and how they've been building African-American archetypes on screen... archetypes that have been around for so long that they became sort of internalized over the years or should I even say over the decades. Now, while I've been here, I had the opportunity to watch some American TV, and I watched a lot of BET, 
Black Entertainment, and on this channel I was expecting the programs to reflect the African American community outside those archetypes, and I was very distraught to see all these clichés about African Americans on screen on a channel that is supposedly 'for' African Americans.

WC: Well, Hollywood doesn't think racism is sexy... So therefore stories that deal essentially with it are muted or dulled or dumbed-down or made palatable so they can make money out of it, so it will be mainstream or, what is the term for it... It has "crossover value". The dominant culture people, whites will watch it, they won't be offended, they won't be upset, that's why you only see African American men who look like idiots. You know, even the rappers, they don't even look like that. There are plenty of good looking African American males around, you know, a lot of them in prison, and they got these clowns to put on a show. Now to be fair, I'm glad that these people are working there, making money, they're supporting their families, they're doing all those good things that a person should do, but goddamn! I would like to see something that's real! Now, right, granted, no one's reality is on television, but there are reflections, there are echoes, something that isn't gonna make me feel ashamed or embarrassed, or want to get up and kick in the television set. And BET is basically exploitation of a mainstream dumbed-down version of the African American community as a whole. Now that is a business, they are selling an image.

cJ: But do you think that what is showed on channels like BET are really shaping minds as to how African Americans should conduct, behave, act, like, don't like, feel, etc..?

WC: The subliminal effect of receiving those similar clichés non-stop are, I think, completely underrated... it's terrible. And it makes it very hard if you do not conform to those expectations. When I show up, I'm expected to act or conduct myself in certain ways. For example, Satchmo, I can't stand Satchmo, Louis Armstrong, the trumpeter, ok. When I was a kid in the 1950's, I just cringed every time he came on, I hated this, everything he stood for, everything he was, except the trumpet playing itself, because I was raised to be a musician, I understand music, I enjoy good musicianship, but the rest of it I could not use. And a few people have pushed him as, you know, he was a great trumpeter right, but they have pushed him as a cultural icon, so I have to turn on TV, or turn on the radio, or turn on cable to listen to jazz, and there's Satchmo. We went for Thanksgiving about a year ago, we went to a friend's house, he thought he was impressing me, he bought like a $5 \mathrm{~cd}$ set of Satchmo. And we're sitting there, and I'm eating, first my ear perked up and I thought, "uh-oh, there's Stachmo", and I don't say anything, because I think that the song is gonna go off, and I can survive one song. Then another one comes on. And then another one. And I said: "What is THAT?! Who soared me back into the 1950's, take that shit off! Turn that shit off, isn't there anything else?!" And I, you know, I don't like being impolite to people, especially when I'm in their house and eating their food! But he didn't understand, he thought that because I'm black I would like Satchmo, or gravitate toward him, but no no no no... And I can't make the same assumptions about my fellows when I travel, that gets me, that's gotten me into some big trouble. Just because someone is African American or Black doesn't mean they understand racism! Because that's a sophisticated, complex, a systemic thing that permeates everything in America. And many of these people wouldn't know it if it bit them. They wouldn't understand - most African Americans they're just in the soup, they don't know what the soup consists of. They can't interpret it - or understand, when you ask them questions, they'll rely on their experience or the experience of 
people they've known, that way they can give you some sort of explanation or context, but most of them, they're not sociologists, they're not philosophers, they're not great thinkers, and that's what it takes to really understand this enormous THING.

cs: But this enormous thing like you said, is firmly rooted in emotional impulses... How to understand something that can hardly be made sense of? Especially when you're the recipient of this hate? When one sees people protesting with banners of Obama caricatured as a monkey, there is nothing rational to make out of it...

WC: Free speech is a bugger! These people are at root racists. But of course they can rationalize...

cs: Can they? One must act on pure emotionalism to dare make those opinions that public because if we pay attention to what they're actually saying, it just doesn't make much sense...

WC: But has it ever made any sense? It isn't about sense, it isn't about logic. Again, you're right, it's a purely emotional thing. It's as simple as being on the school ground. Because that's where I learned about racism and differences. I was in kindergarten, and the teachers organized these little dances and things for boys and girls to interact, and when I reached out to take this little white boy's hand he said "I cannot touch you, you're a nigger". So it's as simple as that. My first love, my first sort of romance, I was seven years old, my family was the first black family to move in to our neighborhood, South Los Angeles, and so I was the oldest of 4 children, and I didn't have anybody to play with when we first moved in, and so - we lived from the nearest cross street, we were about third down the block, there was a house on the corner on the north-west corner, where the two streets intersected McKinley and $89^{\text {th }}$ Street. There was a little house on that corner, and there was a little blond boy in that house, he was ten years old at the time. He would come out of his house, and look down, he crossed the street, and he would look and he would see me in the yard, and I didn't have anyone to play with either, so I'm out there, and we were looking down the block at each other. So I come to the edge of my lawn, and onto the sidewalk and I'm looking and he's looking, and he's bold enough, he crosses the street and he starts to come down the block, so everyday he gets a little closer. And pretty soon, we're playing together ok. He's name was Jarrell. He could come into my house, he could come after school and have cookies and milk with me, he was so bold he used to come by the bedroom window, where me and my brothers slept, he would come in there, by the clanky bedroom window on Saturday mornings, we could watch cartoons together, or go play out in the backyard where we had lots of fruit trees and things. Or we could read comic books together. But I couldn't go in Jarrell's house. If I went down the street, to his house, I could sit on his steps but I couldn't come inside. And when I asked my mother about that, you know, she finally asked me about him, and she couldn't really explain to me, Jarrell couldn't either. And we had really got a relationship, he taught me math, he was a math-head and I had problems at school with that so he would help me. He would teach me how to solve my math problems and what not, but I couldn't go into his house. Those boundaries. They're invisible, but they're very real.

cs: And politics don't seem to be doing much to try and make those boundaries disappear, do they?

WC: Yeah right, exactly! There's no effective, or let's put it this way, the effectiveness of the American left is highly in question as a whole. You know, the Left that's left. 
What remains of it and let's face it, it is the political party that is most likely to tackle the race issue. Whereas the Republicans are very well funded, and are very highly organized and are very effective. Contrasts. Because the stake for them is giving up their wealth and of course they don't want to. People who aspire to that are their allies. So that is how the new natural order needs to be kept, that's really at the root of the war! And it so happens that because of the peculiar history of this country, that that war is rooted within racism. Racism is the root. We got to that by talking about the fear. For example the fear of loss of identity as well as the fear of separation. For example in Los Angeles when housing opened up in the late fifties that was blamed for destroying what there was of a very strong black community in the city. People are still trying to hold on to the Degnan ${ }^{2}$ area for example which is full now, Africans from other parts of the world have settled into that area. There you have Africans who are Spanish speaking or French speaking, on top of their native dialects, coming into that area, a real Afro melting pot. The African American population has been pushed out of the city after the 1992 riots, that was one of the things that happened in the aftermath of the events, far from the media focus that was long gone. To disperse was the new rule, so you don't have a concentrated community of African Americans to move against you, so to speak, so the landlords have been very effective in pushing African Americans into bedroom communities, Rancho this, Cucamonga, or Palmdale, we're living there now because you can't get jobs, they make the city unlivable for you, and force you out of it. And that's essential of what has happened in post riot 1992 Los Angeles. It happened before that after the riots of 1965, and before that, just the act of opening up housing, because housing was segregated, we had red lines, my parents could not live in other parts of the city, they had to live in South, which became South Los Angeles and later South Central and is now going back to South Los Angeles again. To take away its Black identity, even that has to be taken away, we cannot have anything that is holding...

cJ: Changing names is the most effective way of erasing any hold over a past history, it's the best way to start fresh and forget about what occurred there before. To that extent, Los Angeles has become expert in its branding and rebranding strategies as it relied on them from its very start, didn't it? And in that case the very name had to change to erase any traces of African American identity and the turmoil it can evoke...

WC: Exactly! So there's this constant upheaval, disruption, disconnection, disjunction, all these things are part of my work. So I'm focusing on how, since I've lived this, since I've lived the city. I mean even Farrakhan (Louis Farrakhan) was run out of L.A. One of L.A. talk-show hosts was knocked off the air for having Farrakhan on his program. I'm not especially comfortable myself with Farrakhan preaching again a separate but equal philosophy, and I don't know, since I've only seen Farrakhan speak a couple or three times, and listen to him, and I really have not been in that kind of inner black circle, so I really don't know what he really thinks and what he's really about. As far as the Black Muslim community and the Nation of Islam is concerned, it's been pretty much uprooted and forced out of Los Angeles in the similar way Motown was forced out of Detroit and came to Los Angeles. So I couldn't argue the strengths or weaknesses, well, I don't see any strength in the Black Muslim community, I only see the weaknesses because they have an economic philosophy; and the only way that philosophy could be successful is as if they were able to bring the Black community together, some sort of cohesiveness. But the dominant mainstream culture has gotten wise and well aware of that and they're going to see to 
it that that cohesiveness doesn't take place. We're not gonna have any more Harlem. We're not gonna have any more South Centrals, we're not gonna have any more South Sides of Chicago.

cJ: So dispersion became the new rule to abide to?

WC: That's right and we're not gonna have that anymore. So, in the light of that, the Black community becomes this sort of psychological and amorphous thing, and the nature of L.A. is already amorphous. With all the pools of ethnocosms. I mean there's no coincidence. Let's take a very clear example about how that cohesiveness doesn't work within the African American community... To get a liquor license in the state of California, if we go back a generation, it was $\$ 50,000$. Well, no one ever seemed to be able to amass the $\$ 50,000$ to buy a liquor license except Chinese, Japanese, Filipinos, Armenians, a few Mexicans here and there, and Jews, because those are the only merchants, with Persians and Koreans, who are able to share investments in order to share profits. It seems that the same strategy has been impossible to get within the African American community! Because that poison was put in our community, so to speak, with the exploitation, the economic exploitation that takes place, governed by the merchant class... There was no Black merchant class. Ethiopians have, little by little, developed a merchant class here, there are Black entrepreneurs, there are African Americans who managed to amass money and fortunes, BUT how come things don't change effectively? You've got, you know, gazillionnaire Oprah, you got gazillionnaire Tyler Perry, you got athletes who have, you know, "beaucoups bucks"... why doesn't it really change? What is it, at the root of this country, that the African American community has crystallized at the core of our collective identity to make that cohesiveness virtually impossible to articulate? Huh? Like anybody else, African Americans can amass money, but the money is not effective. It's not effective. Why? Why? Why?... That is the question. As a postwar baby growing up in Los Angeles, I've witnessed things getting better and better for other communities, Asians in particular, but also for the Latinos, and it has nothing to do with their growing number... Why not us? And so I'm constantly examining this, I'm watching all this take place, I'm asking these questions, and that creates that tension, those tensions, Our wealth provide me with a wealth of material. So I never have to worry about running out of things to write about. I could use running dry, I could run out of a few things, it wouldn't hurt!

cJ: Do you think that the amorphousness of the city, as you described it, has been an increasing factor in Los Angeles for this lack of unison within the African American community, even though Watts and South Central/South L.A. were and still are predominantly African American neighborhoods?

WC: I think so because in those neighborhoods you mentioned, there are no places where African Americans can get together to think and talk it out. And so to speak, outside of the African American community, it has also been very hard for local artists and authors to find a voice outside of Hollywood, especially when Hollywood does not want you! We don't have any Algonquins, you know, the famous hotel in New York, so people getting together and clustering together and having this rubbing up against each other, and having this dynamic take place of interchange and intellectual development. It's been very difficult to develop the same dynamics in here, in Los Angeles. It has happened to an extent, but it is governed by the terrain, it's governed by your ability to get in that car and drive there. You gotta go to it because it's not stationary. It's not in one place, like the city itself it's fragmented and 
scattered. There have been many attempts and there still are, there are still people doing things. Now the Getty just started this huge initiative for visual arts, organizing all these galleries from around the world, inviting people from around the world to look at art in Los Angeles. Now this started at the Pompidou in France! See if the Pompidou hadn't looked at Los Angeles you see, here we are, 5 years later, with the Getty and the Museums, LACMA etc., all organizing this Pacific Standard Time event together, but that wouldn't have happened if it hadn't happened at the Pompidou first in 2006.

cJ: Oh really? I've seen the exhibit you're talking about and I was not surprised about the vivid local artistic scene which I had already partially encountered when I lived here, but I was quite pleasantly surprised to see that similar works I saw in very small, barely surviving galleries back in 2003 were suddenly gaining visibility through this exhibit. What I was absolutely not aware of was the impact that this exhibit could have on Los Angeles. You really believe that without this sudden spotlight on the Los Angeles artistic scene in Paris, the Pacific Standard Time would not have had the magnitude it does?

WC: Oh absolutely. We're still very, in a sense and very paradoxically, Eurocentric here. Here in Los Angeles as in the rest of the U.S. Even among African Americans. France has been very important in our history, and in our psyche, and in our cultural development. France and Great Britain. Those two countries, because of being world powers at one time, and dominating western culture have affected us, and so many Americans always have one eye on Europe. And in terms of artistic value, the New York scene was able to break free of any European validation, but as for the rest of the U.S., not so much... If you consider $\mathrm{ASCO}^{3}$ Gronk or Harry Gamboa, two Los Angeles chicano artists ok, I have a Gronk napkin, I asked Gronk to do a drawing on a napkin for me once, I have it in a scrapbook somewhere.... But, these artists had to have their work recognized outside of the United States first before they became famous within the States. And that mechanism is still at work. For some artists it's gonna be Italy, for some it's gonna be somewhere in Spain, or elsewhere and then they come back here and you get your dues. Very similar with New York for Los Angeles! For years here, it's all I've heard! "Wanda, go to New York", "Wanda, got to New York", "Go to New York", "Go to New York". I don't have bus fare "Go to New York", I don't have plane fare "Go to New York!" I've got children, I've gotta work, I've gotta feed my kids "Go to New York!" So, going to New York, which is seen and valued as the cultural heart of the United States, has always been presented to me as the endgame. From New York you can access the rest of the world, it's much easier. Someone told me: "Wanda, if you can't go there, at least get a P.O. Box in New York!" Didn't have no money to do that either, so I just had to tough it out here in Southern California because I couldn't travel, I couldn't get to those places. I always had to make the choice between real food and cultural food.

cs: Has it become the new normal for local Angeleno artists to work here first, perfect their craft on their turf to then delocalize to New York in order to get recognized before coming back once success had been achieved?

WC: It has! It still works. Going out there and getting a reputation. Or if you're lucky like Brett Easton Ellis, Less Than Zero, well, as soon as he got famous, he was in New York! Or, Walter Mosley, it's very interesting. Walter, when he was going to Crossroads ${ }^{4}$ school and he was a student, I came to his school and I read my poems there and talked to the students, and he was one of those students, and he later said 
that I influenced him and he decided he would learn how to write, he would pursue his writing and as soon as he got famous, he fled to New York also. So... I'm still here.

cJ: Was there any resentment growing on your part for never making it there, getting the validation from somewhere else...? Or outside of any New York validation, did the L.A. cultural scene suffocate you at times? Does it still?

WC: Well, it's starting to change here. Finally!! We have the internet, we have technology so communications have opened up to a large extent. You know, I would go to somewhere and I would say "I'm the major African American voice in the 2nd largest city of the United States" and they would stay mute, like "what does that mean?" because for a lot, they haven't heard of me. When I get to New York, it's rarely on business, and I've been to Manhattan more than a few times, but I never lived there, I haven't invested myself in that cultural terrain. Aside from that, if we ponder what happened locally...I have to say, the Los Angeles Times has governed the cultural turf here for a long time and it's been very racist at its root. Even when I worked for the paper it didn't support me, I wasn't made a part of it, I was still kept separate from it. It doesn't review my books for the most part. Maybe two of my books have been reviewed favorably by the L.A. Times, but then I had to be a part of the organization PEN, if I wasn't a member of PEN ${ }^{5}$, my books didn't get reviewed. So there are all these dynamics going on and the Los Angeles Times now with the technological change, there isn't even book reviews. So the opportunity for me to get that is even less than it was a generation ago. That has been a contributing factor to a lot of fine writers who live here in the West. Across the demographics, the Los Angeles Times has had a great impact on my generation of Los Angeles writers. Now if a writer or an artist in New York and they do their work there, immediately, if they have any sort of recognition, they're immediately embraced by the local critics, they're considered citizens of the world. But if you have recognition in Los Angeles, you're considered a citizen of Los Angeles, see? It's hard to even become a Californian! You know?! Or an American! You're put in this, again, a stereotype, or this box that says L.A. on it, you're put in that. You're parochial, you're local, all the negatives amassed...

cJ: But why would being a local writer be such a negative? Many American authors strongly attached to a place, New York, New Orleans, Chicago to cite but a few, have been celebrated in accordance to this connection and critically acclaimed at the same time, no?

WC: Indeed! But in L.A., locality being so infused by Hollywood that culture is deemed inexistent or if it exists, inconsistent. Being an African American woman in that box, can you imagine? If we take a step back and look at the writers who've won the nobel prize, would you call them parochial? They were in their place. I don't think this man who just won the prize, Tomas Tranströmer, he's only written about 200 pages of text that he's had published, he was in his little space and didn't go anywhere, and he's being honored worldwide and most of the world has never heard of him. But somehow, if I were in the same position it would be a negative. I wouldn't be worthy of such a prize. That's a negative for me. If I stayed in my place and only write 200 pages, what, I'm nuts! Some of these things can be embraced, others cannot. I found out from a judge one day that I got denied a prize, a literary prize, because my prose was poetic. You can't take a literature course without some professor somewhere waxing eloquently about how this writer's prose is POETIC! But when it comes to me, all of a sudden, it's a negative... And I like playing with form, this book was Native in a Strange Land, that was the book that I'm talking about here. 
cJ: Yes, the first book of essays you published about Los Angeles and your experience of the city?

WC: That's the one yes. But the poetic vibe of those essays was somewhat disconcerting for some and it cost me a prize because writing a book infused with poetic about my life in Los Angeles was apparently too destabilizing for some... Because I write on multiple forms, that I like to think of myself as a fusionist. I like to go in and out of forms, and I love rhythm, I started out as a musician, so I have an ear for music, and I like to do musical things, even within my prose. Now, and I do things that some people can't hear, because they don't have the ear or the same musical jazz background. The piece you mentioned earlier, "Angel Baby Blues", which is based on a traditional blues song. In it, I'm doing a cultural reversal: "a man is a two-face, a worrisome thing who'll leave you to sing the blues." It's the "blues in the night". So I'm doing that, I'm taking those rhythms, and I'm interweaving them into my texts like in "Angel Baby Blues" and I'm giving you a clue by reversing the lyrics in the song, I'm telling the reader that that's what I'm doing, this is the code, this is the key for you to unlock this particular door, the writing door that I'm gonna go through, this aesthetic door. Here's the clue, you know, here's the piece when I talk about being an angel, baby.

cJ: Now if we come back to the general purpose of your work which is to "rehumanize the dehumanized" and look at it maybe a little more retroactively, would you say that you are what the city expects you to be, or what the city needs you to be?

WC: Probably what the city needs me to be. What the city expects me to be is dead! And I'm not dead yet! I'm getting there, I will get there eventually but... I think that metaphorically speaking, yeah it expects me to be dead, dead as a talent, dead as a voice. It has not afforded me squat, I've had to make my own way, I wasn't given anything, I couldn't complete my education, it was too expensive. So I was never able to make enough money to pay for my education, my grades weren't good enough for scholarships, that's a whole new story... First of all, how do you learn when you're in class with racists as instructors? Are they really going to teach you anything? Are you going to pay money that needs to go to the landlord, or to the utilities, or to buy your kids clothes or feeding them, you really gonna pay to have some racist professor not do his job and not teach you anything? Really?! That's where I came to terms with education. What decided me to drop out of college, was that I was driving- I mean, you know, L.A.! You have to DRIVE to get there! So I'm driving all the way to the San Fernando Valley or to Hollywood or wherever, to go to school from South Central, I have to spend money on gas I can't afford, I have to buy books I can't afford, I try to look decent given the fact that I can't afford clothes. One day I got sick in class, I wasn't eating, I was going 3 to 4 days without food so that my kids could eat, and still doing this rhythm of working two jobs and going to school too. And I got sick in class I'm sitting there and I'm starting to moan and go down my chair... I come down with a virus of some sort. The people who were around me then treated me like I was a junkie in withdrawal... And no one volunteered to help me in that classroom. Except one woman who finally volunteered, she found me about 15 years later and told me her father was a leftist! Ah! And she was the only one who volunteered to take me down. I don't know where she took me, I don't even remember, I only remember that I had my mother to meet me there, I think there was a hospital in the area, and I went to the ER there, she took me there, and left me there. But that made me wonder, why am I torturing myself? What am I doing this for? Because I want to be a poet? A 
writer? And I wanna make money, and raise my family... Also I was taking a film course to the school that is now CSUN, before that it was San Fernando Valley Junior College or something like that, and when I went to that classroom to sit down among the other students, there were only two blacks in the classroom, and the chair of department was teaching that class. When I came in, it was like, he went immediately rigid. Whenever I would come in the classroom, he would get rigid. He would be teaching everybody but if his eyes would just go over me, he would get this little like "uh, I'm looking at it, oh my God". You know. He would wince, and tried not to look at me. He would spend the whole hour standing there, trying not to look in my direction, and not meet my gaze. And I'm sitting there, and I'm thinking: "I'm paying this man, paying his salary, but why am I here? What for? I'm paying for something I'm not gonna get?!" That's what happened to my education. Now rehumanize the dehumanized...ultimately that phrase goes directly back to the Los Angeles Times, I can't tell you how often reading the paper infuriated me... The first black reporter hired by the Los Angeles Times was hired, off the street, following the Watts riots in 1965. And subsequently, when stories appeared, when they appeared which is rarely, but they're usually crime stories that appear on the Blacks, that relate to the Black community. There's no context for these stories. So our truth is always absent from context. So I'm reading this story about this incident, and I say: "there are things missing here". Knowing an African American in a given situation, there's a lot we don't know about the story, we're just getting the surface, the result, the mistake if it were one to begin with. We're getting what is digestible to the middle-class white reader who picks up his newspaper. But there are other things here that that reader needs to know. So literally I started clipping, I started saving these clips, these newspapers clips, and some of them have become poems. The poem, my poem consists of the context. The context that's missing becomes my fictional material.

cJ: Do you somehow feel like it's your responsibility to provide that context?

WC: Well, if I can see it, it's the responsibility of whoever sees, to provide the answer, right? Not everyone does, some people who see don't provide any, they exploit the situation. In my case, I have opted not to exploit it. It's an individual call, an individual choice. Because I've seen myself there... empathy comes right back at us! But apart from empathy, all that has happened to me, where I'm in a situation, and I'm dehumanized. That essentially defines the mechanism, how racism works. I enter a store, it's immediately assumed I'm guilty of something so I'm suddenly being watched. Why am I being watched, because it is assumed that I'm going to steal something. I'm a thief so, when I approach a store, I'm a customer, but when I go through those doors, I'm a THIEF! What's changed? What happened in that space, in those seconds and when I entered the building? I didn't change! What changed? The environment changed. So outside of this environment I'm a customer, inside, I'm a thief.

cJ: But then again, have you ever been to places in the US where you didn't feel that way?

WC: Rarely. I mean, even getting on a plane, I'm a terrorist! I was a terrorist on my first local flight to San Francisco! First time I got on a plane, circa 1964 or 65. I was searched, my bags were searched. All the things that the people have to go through now and oh my god, it so tickles at times, because the rest of the nation has finally joined me thanks to those brainwashed imbeciles who drove those airplanes through the world-trade center! 
cJ: That's what it took for people to understand what it feels like to be assumed guilty.

WC: Yes, that's what it took for the rest of America to start to experience what I have to experience since 1962 and here we are in 2011. See? When I was 20, 20 odd years old, I was already a terrorist. And if I had to get ready to go fly somewhere, I had to be searched as if I were entering a jail. They did everything but delouse me. And it was very interesting because the two white people I was travelling with were not searched. And they were the guilty ones. I mean the woman had some dope on her! She was dirty. And I didn't even smoke! But she had marijuana on her. But I was the one who was searched. This thing of image that Hollywood puts up that's so important, it has to be paid attention to. Significantly. I was looking at television last night and they announced the Nobel Peace prize that went to the three women. And when you looked at the three, one was old, one was very round made of ovals kind of like an African woman, the other one was a very dark-skinned woman... there they were, three dark skinned-women and looking amazing! Now I'm looking at these three images and I'm thinking that it would be lovely to see more images like that in the media. You don't see images like that here except on select networks. You don't see leaders of color. Now when we were in Paris particularly, one of the things that I loved doing was watching television there, so that I could see what the leaders of the world looked like in other countries! I saw people that I didn't see here at home. But at the same time, the only image I saw of a black woman in Paris was Martin Lawrence in a fat suit for his Big Mama movie... In the metro, there was this big poster of this stupid movie, another stupidity that he's forced to make if he wants to live. That was the only image, a man in a fat suit, dressed up, pretending to be a woman, that's the only image of a woman of color I saw the whole time I was in France. How's that for conveying a completely false imagery and imaginary of African Americans, even transcending borders?!

\section{cJ: That's the power of Los Angeles, isn't it?}

WC: It is and well, with all its power, it will not take any kind of responsibility for it. Maybe it will one day, but I won't be there to see it.

CJ: I'm an optimist, so let's say that I'll be around to see that! Now, how would you say that all those paradigms we discussed about Los Angeles and racism have manifested in the city as of late ? Observing the city's political and cultural life from a distance, it seems that the enclaves are seriously starting to shift, for better or for worse, with the downtown renewal program pushing the homeless population that huddled there out of its streets, or the scattering of some communities like that of the African Americans as you have previously commented upon... Aren't there new patterns appearing, new habits taking roots?

WC: Exactly. You know, the Watts Towers Art Center is in trouble or was in trouble, I haven't followed the last developments... I used to play on those when I was a kid, we used to sneak out of the house at night when I staying at the babysitter's. She lived on the $104^{\text {th }}$ street and that was just three blocks from the towers. And so at night we would go out like this little gang and we'd go down to the towers and play there at night. And climb them whatever because Simon Rodia he'd get paid on Friday nights and he'd go cash his check and get drunk. An so we watched him sort of stagger around the house and as soon as he left, we'd run in there and start climbing. And what has happened is that in dispersing the African American community that huddled in South Los Angeles, the Watts Towers Art Center is endangered because it represents a community that is no longer there... See it would be wonderful to have 
an open society, but our society is only opened to certain people and our country is very hypocritical and two faced about immigration. In Southern California, especially in Los Angeles, Latinos have been brought to help and disperse us. They helped disperse the African American specifically.

When we decided to change from our apartment post 1992 riots, we discovered that landlords wouldn't call you back if you didn't have a Spanish accent. If you called and they detected that your voice or your manner of speaking was African American, they wouldn't call you back. So we decided to play a little game... My sister in law is from Toulon. So we have her call instead, just to find out, as an experiment. So she would call and they would call her back. But if one of us called, no answer. Same with renting. With Austin we were trying to get an apartment in a certain area of town and we went, we had set up an appointment to meet the landlord, we were standing outside the building and I said: “Austin, they've been here. They're here, but they see us, and they're gonna leave us standing here." So that kind of discrimination is still practiced in Los Angeles, regardless of what the law says. There are still these red lines. There are still these divisions taking place, they just find a way to get around the law to get around the punishment because discrimination has been made a crime. It's not enforced. It still goes on. So here come these poor Mexican or Nicaraguan people, and coming to the United States, they think that they're going to be allowed into this open society, that the society is gonna welcome them, and they get here and they find out it isn't. They're being used, they serve a purpose, they have taken jobs that once sustained the Black community. All those little jobs, working at the fast food place, working at the car wash, those kind of temporary jobs that people would take until they could move on to something better, now people come and they're in these jobs forever! It's better to have a job than none! So they come here and they stay in those jobs so that's what's happened.

So if you're an African American, if you had a job at a place where people were racist, well you could always quit and go back to the car wash, quit and go back to the juke joint, quit and go back to whatever. That subculture was supported and sustained by those kind of low-leveled jobs. You can't do that anymore, they're not there anymore to sustain you. So if you quit, you're just fucked! There's no place for you to go! Except the streets and there are plenty! That's why there are so many homeless Americans. Because they can't go back to those jobs, and when they want to go back to those jobs, people have accommodated.

I went to a publisher and I wanted to be hired and he gave me a test. He gave me two tests. The first test was in English. Well, when I was in the revolution in the 60s, I memorized an English book, a grammar book. So when he gave me the quiz, I was like 99\% and he couldn't believe it. He said: "No one has ever passed this test in my entire business life! You've got the highest score of anyone I've ever seen!" And I said: "Oh thank you". But did I get the job? He couldn't stand it. So what did he do, he went back and he gave me a math test. For an editing job! So it would bring my score average down! Then he had an excuse, then he came back and said "well I can't hire you because you're only average in math. It brought your score down." See, THAT is the way the game is played. There will always be some reason why not. Constantly shifting, I refer to that in the title of my book African Sleeping Sickness which is after a virus which is similar to the one in the movie The China Syndrome, a virus that morphs, so the minute you cure it, it takes another shape and continues to 
proliferate, that's what racism is like. Every time you think you've cured it, or you solved it, it morphs. So you will never be able to overcome it.

You know, the first time I came into contact with racism in a very violent way was when I entered the American school system, and when I got out of it, when I graduated, I read plenty of books on hypnosis. And one night I stood in front of a mirror and practiced those methods on myself. I self-hypnotized myself into forgetting all that I had to go through, not the events themselves or the anger they stirred, but the pain they inflicted on me...

CJ: did it work?

WC: You're talking to me now...

\section{NOTES}

1. She refers to Darnell Hunt and Ana-Christina Ramon's book Black Los Angeles: American Dreams and Racial Realities.

2. Degnan is a street in the Crenshaw District of Los Angeles, which includes the Baldwin Hills. It was a very racist, exclusively white part of town until the Baldwin Hills dam burst in 1963, the winter before I graduated High School. Whites vacated the area en mass and Blacks were allowed to buy the very nice homes and properties they left behind. By 1964 Blacks were literally partying in the streets, celebrating the largest upscale African American community in the city's history (other than Sugar Hill in the Adams area and Altadena, next to Pasadena). The area was flooded with middle and upper class Blacks and street fairs and celebrations took place in the "downtown" or plaza section of the community off $43^{\text {rd }}$ and on Degnan (plaza's are rare in Los Angeles. There are only two true cultural hearts that I know of, Degnan and Olvera Street). Clubs, art galleries, shops and restaurants opened. For 40 years-until a new immigrant population of blacks from other parts of the world began to settle there-the area was the city's center of Black culture other than what survived in Watts-Willowbrook and Compton. Those areas are now largely Latino because land owners and real estate rogues have run Blacks out of our old strong holds. There has been a conscious effort among black community leaders to keep the Crenshaw District largely African American. This effort seems to be failing. It is an area I have often visited over the years, as a consumer and to read my poetry, but I could never afford to live there.

3. Artist collective from East Los Angeles.

4. "Crossroads" is a private K-12 school located in Santa Monica (what used to be called an elementary or grade school when I was a child). It is considered one of the best schools of its kind in California. Like many private schools, the parents of its students are primarily high-powered professionals-many in the entertainment business. I have been invited to read my poetry at Crossroads 6-7 times over the decades. Two of the former students who have "looked me up" after achieving some success as writers, and thanking me for my inspiration, are crime novelist Walter Mosley and actress-poet Amber Tamblyn (daughter of actor-dancer Russ Tamblyn).

5. P.E.N. (pronounced the same as "pin") is a writer's organization. They've taken out the periods which abbreviate Poets, Essayists and Novelists. They are now called PEN, and their headquarters is PEN American Center. They have chapters all across the country. I was given an honorary membership to the L.A. chapter in 1983, then became a vice president years later. It's always 
been very influential here, more so than the WGAw (Writer's Guild of America, west) or the more recently formed Writers' Union. I believe that at least two of my books (definitely A War of Eyes) were reviewed because of my membership and vice presidency. I am usually mentioned when the topic of Los Angeles writers is generally discussed-as one of the few African Americans still living and working in this city. Otherwise, the book editors at the Los Angeles Times have not had my books reviewed.

\section{AUTHOR}

\section{CHARLES JOSEPH}

Charles Joseph completed a Ph.D. in American Studies; his dissertation, entitled Being and Writing (from) Los Angeles: Wanda Coleman, examines the complex and evolving relationship between the work of the African-American author and the city that harbored her birth, life and death through the prism of cultural studies. He has simultaneously developed an interest in the implications and practices of the entertainment industry based in Los Angeles on the city's history and the shaping of its socio-cultural identity, as well as its influential role on the mass transmedia. He has published articles in Les Chantiers de la Création, ORDA, Conserveries Mémorielles, ANGLES and Urbanities. 